\title{
Expanding The Accounting Education Horizon: Sensitizing Students To The Profession's Societal Obligations
}

Brian W. Carpenter, (Email: bwc352@scranton.edu), University of Scranton Daniel P. Mahoney, (Email: Daniel.Mahoney@scranton.edu), University of Scranton

\begin{abstract}
This paper presents an alternative teaching pedagogy that goes beyond the learning of complex rules to provide accounting students with a better appreciation for their profession's societal obligations. The proposed pedagogy presents students with the evolution of accounting standards in a given topical area, and challenges them to evaluate the extent to which the different stages of evolution succeeded in meeting the profession's obligations to society. These obligations are defined in terms of the financial reporting objectives set forth in the Concepts Statements of the Financial Accounting Standards Board. The proposed pedagogy is offered as a means of addressing problems with respect to the more conventional "memorize these rules" method of accounting instruction. Our aim is to develop students who take a greater interest in the standard setting process and in fulfilling its promise of meeting the financial reporting needs of society.
\end{abstract}

\section{INTRODUCTION}

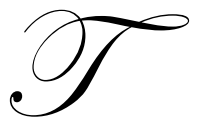

he conventional financial accounting curriculum is dominated by a very detailed "standards focus" in which students are taught the specific requirements of a myriad of accounting regulations. This dominant focus is made necessary by the ever-increasing complexity of financial accounting standards, which of course requires a greater time commitment within the instructional process. Because student knowledge will ultimately be assessed in professional certification exams (CPA, CMA, etc.), the accounting education process is understandably driven by the need for students to "learn the standards." However, while it is essential that students acquire an understanding of the rules of accounting and financial reporting, one might argue that the dominance of this focus has its disadvantages. For example, this emphasis currently leaves little time for meaningful discussion of the profession's obligations to society and the effectiveness of the standard setting process in fulfilling these obligations. This inability to devote sufficient time to such critical issues may lessen student awareness of the degree to which corporate interests may sometimes dominate the standard setting process. In fact, the current normative approach used to teach the standard setting process may be so abstract as to negatively affect the quality and breadth of future participation in the process.

It can be argued that as future members of the accounting profession, students should be exposed to the standard setting process in such a manner that it heightens their appreciation for the profession's societal obligations and increases the likelihood of their productive involvement in the fulfillment of these obligations. The conventional teaching approach is too focused on the immediate short term needs of students and employers to adequately address this longer term, but critically important, professional and societal need.

The purpose of this paper is to present an alternative pedagogical approach intended to enhance classroom discussion of the profession's societal obligations and the extent to which the profession's standard setting process fulfills this obligation. This proposed pedagogy offers potential long term benefits that might arguably have far reaching effects on the likelihood and nature of future student participation in the standard setting process. The proposed alternative also suggests that a shift in classroom focus -- from the normative details of the standard setting process to the 
more fertile examples of actual evolutions of accounting standards -- will likely provide students with a better appreciation for the accounting profession's obligations to society.

This paper uses pension accounting as a means of illustrating the proposed teaching pedagogy. While pension accounting standards are viewed as being exceedingly complex, the development of these standards provides a remarkably revealing history that is understandable, predictable, and replete with issues that clearly illustrate the problems that often arise in the promulgation of accounting standards. Discussion of these issues would underscore the importance of properly safeguarding societal interests and help illustrate the true significance of the ideals identified in the Conceptual Framework. Our primary goals are to produce accounting professionals who are: 1) more sensitive to the obligations the profession has to society, 2) more likely to ultimately participate in the standard setting process, and 3) less likely to do so in a way that is motivated solely by self interest.

Before proceeding with a detailed discussion of the proposed teaching pedagogy, it is important to first elaborate upon an issue that is largely overlooked within the typical accounting classroom. Most accounting students seem to walk away from the classroom with little recognition of - or appreciation for - the role their profession ought to play in the broader society. Since the proposed teaching pedagogy is intended to address this shortcoming, it is worthwhile to examine the issue of societal obligations.

\section{THE PROFESSION'S OBLIGATIONS TO SOCIETY}

Society looks to the accounting profession for assurance of meaningful and reliable financial information. Indeed, the profession itself has clearly acknowledged this obligation. To help guide the profession in its attempt to produce sound and socially beneficial accounting regulations, the Financial Accounting Standards Board (FASB) undertook a Conceptual Framework Project. The goal of this project was to promote the quality of future accounting standards by ensuring that the underlying standard setting process was guided by uniform and consistent ideals. The FASB has, to date, issued six currently effective Concepts Statements (see Figure 1).

FASB Concepts Statement No. 1, Objectives of Financial Reporting by Business Enterprises, states the primary objective of financial reporting: "Financial reporting should provide information that is useful to present and potential investors and creditors and other users in making rational investment, credit, and similar decisions" (paragraph 34). Few would argue that recent, well-publicized financial reporting debacles have called into question the extent to which the accounting profession is living up to its critical societal obligations. However, even in the best instances where financial reports fully comply with generally accepted accounting principles, one could potentially question whether the profession is in fact promulgating rules that assure the provision of financial information that is useful to all interest parties. Concepts Statement No. 2, Qualitative Characteristics of Accounting Information, presents a hierarchy of qualitative characteristics that are supposed to be reflected in reported financial information. Of paramount importance in this hierarchy are "relevance" and "reliability." Of course, the FASB offers clear definitions of these critical qualities. Unfortunately, the provision of so many definitions within one topic likely overwhelms most students (see Figures 2 and $3)$.

The conventional textbook coverage of the ideals and goals set forth in the Concepts Statements - and the manner in which those ideals and goals help ensure that the standard setting process is fulfilling the profession's societal obligations - employs a single chapter of both the introductory and intermediate texts. Students typically feel compelled to memorize the numerous definitions introduced in these chapters. As illustrated in Figures 2 and 3, the demand for such memorization presents a rather daunting task even to the most eager and conscientious of students. The highly normative approach used in these chapters relies extensively on the use of flowcharts and figures to illustrate how the ideals found in the Concepts Statements guide the promulgation of new accounting standards. As seen in Figures 4 and 5 , students are presented with a myriad of terms and their respective classifications and sub-classifications, all of which constitute an understandably boring approach to the study of the profession's societal obligations. These flowcharts and figures likely undermine the effectiveness of the learning experience by presenting sterile abstractions that tend to fuel the students' propensity to memorize rather than synthesize. Such a tedious approach to learning obviously poses the risk of severely dampening student enthusiasm toward the entire issue of the profession's societal obligations. While 
students are made aware that the FASB's Concepts Statements were created to help ensure the quality of the standard setting process, they find themselves having to take this premise at face value.

Rarely, if ever, are students exposed to the more important aspect of standard setting, which is the deliberation that underlies the compromises found within the political process. The result of this approach is a form of classroom discussion that fails to reveal the political nature of the true standard setting process. One of the dangers of this approach is that it may instill a false sense of security in the students in which they feel as though the "perfect world" scenarios represented in the flowcharts, figures, and definitions actually represent the reality of the standard setting process. In such a perfect world, societal obligations are always fulfilled, user needs are always met, and there is little, if any, need for impartial input into the process.

It is disappointing that student recall of classroom discussion of these topics is most likely dominated by such minutiae as the minimum number of days that an exposure draft is available for public comment or whether "representational faithfulness" is a "constraint," "quality," or "element" of financial information. This focus on the details - rather than the spirit - of standard setting only serves to further dampen any enthusiasm concerning ultimate participation in the standard setting process. That is, students do not feel comfortable in their knowledge of the actual standard setting process, in part because current instructional methods have made the standard setting process seem unduly abstract and distant. It is therefore not surprising that most people who involve themselves (e.g., via input to the FASB's due process) in the standard setting process are those who have a vested interest in the ultimate requirements of a given standard. Those who lack a vested interest will never likely feel compelled to overcome their discomfort with the process and thus are unlikely to ever take part its underlying deliberations. In turn, the process is almost universally comprised of input from auditors, preparers, analysts, and others directly representing business interests. The interests of the public at large can arguably be said to be under-represented.

The key problems that we've identified with the current method of instruction can be found in Figure 6. The primary deficiencies that were cited for the conventional teaching approach were that: 1) it treats issues in a superficial manner, 2) it encourages students to memorize terms and relationships which hampers the long-term retention of the material, 3) the emphasis on terminology and memorization is tedious which dampens student enthusiasm, 4) the treatment only refers to the standard setting process in a normative, abstract manner, 5) it tends to make the process seem like a complex "black box" which in turn lessens the likelihood that students would, in their later careers, participate in the process, and 6) it systematically tends to ensure that the standard setting process is dominated by the self-interests of those who feel comfortable with the perceived complexity, which in turn, may bias the process.

Classroom coverage of the Conceptual Framework - and its reflections of the profession's societal obligations is understandably perceived by students as a dull and tedious topic of study. Furthermore, the mere memorization of definitions is unlikely to provide students with a basis for assessing the strengths and weaknesses of the accounting standards that they study in later chapters and courses. An overlooked long term consequence of the current approach is that it may foster a student attitude that may negatively affect the quality of future participation in the standard setting process. The traditional approach to the study of the FASB's Conceptual Framework can therefore be argued to be deficient, thus creating the need for a more innovative and effective instructional pedagogy.

\section{AN ALTERNATIVE PEDAGOGICAL APPROACH}

The aforementioned problems have long-term consequences that may seriously undermine the safeguarding of societal interests with respect to the promulgation of accounting and financial reporting standards. An alternative teaching pedagogy would thus seem warranted. We contend that effective student exposure to the standard setting process and the profession's associated societal responsibilities requires a less abstract and memorization-intensive approach. Accordingly, we propose that the study of these issues be grounded within the study of the evolution of a particular accounting standard. For purposes of this paper, the evolution of pension accounting is used to illustrate the benefits of our proposed approach. While the issue of pension accounting is used as the vehicle for illustrating the proposed pedagogy, other accounting standards can, and should, be considered for use by accounting instructors. 
The primary advantage of utilizing an historical analysis of the evolution of a standard's creation is that it provides a context and depth that are currently lacking in the more commonly used memorization-driven techniques. We believe that our proposal offers long-term benefits that could mitigate many of the criticisms currently faced by the accounting profession. The foremost benefits of applying this pedagogy are that students develop: 1) a deeper understanding of the standard setting process; 2 ) an appreciation for the profession's role in, and obligations to, society; 3) a more logic-based, rather than memorization-based, understanding of a myriad of accounting issues; and 4) an increased propensity to participate in the standard setting process later in their careers.

\section{The Example Of Pension Standards}

Pension accounting is replete with illustrations of conflicting corporate and societal goals. Key points of this history clearly illustrate how the creation of accounting standards for pensions required that compromises be sought between the frequently conflicting corporate and societal interests. Even though pension standards are extremely complex, the evolution of these standards is predictable, logical, and based on easy to comprehend compromises between various competing interests. Accordingly, the evolution of pension accounting standards provides an exceptionally rich context for classroom discussion of the standard setting process. The most beneficial feature of this evolution is that it illustrates a process whereby each succeeding standard was based on political compromises, and represented -- at least initially -- incremental progress toward a relatively clear long term goal. Importantly, it can be argued that the recent activity in this area represents a divergence in the evolution that is not consistent with earlier goals of prior standard setters. The discussion of this apparent divergence provides a uniquely beneficial opportunity to focus on the tradeoffs that the accounting profession must make when attempting to satisfy competing constituencies. In turn, this discussion of tradeoffs helps sensitize students to the issue of whether the current process adequately satisfies the profession's societal obligations in a manner that is not likely to be equaled by abstract flowcharts and diagrams.

\section{Addressing the Problem of Need for Memorization}

Current classroom coverage of the accounting profession's obligations to society encourages student memorization of the qualitative characteristics, elements, and objectives of financial reporting as found in the FASB's Concepts Statements. Obviously, the task of memorizing the dozens of terms that are suddenly introduced to them is not only tedious, but also tends to significantly dampen student enthusiasm and interest. It is doubtful that students experience much of a long-term benefit from the mere memorization of terms such as "feedback value," "representational faithfulness," or "comprehensive income." The resulting superficiality of their knowledge likely decreases their ability to effectively use their knowledge to effectively evaluate the merits of the various accounting standards found in their later coursework.

In contrast, the proposed examination of the evolution of a given accounting issue would allow students to learn and apply the terminology within a meaningful contextual setting. For example, a study of the evolution of pension accounting would allow students to consider the extent to which, at various stages of the evolution, the standard setters have succeeded in making the newly required pension information more "relevant," more "reliable," sufficiently "neutral," and "representationally faithful" of the reporting company's pension costs and obligations. This contextual application of the terminology sharpens student understanding of the ideals set forth in the Concepts Statements, and thus likely provides them with a greater comfort level with respect to their ultimate willingness to engage in the standard setting process.

\section{Addressing the Problem of Superficial Coverage of the Standard Setting Process}

As with the study of the evolution of any given accounting issue, an examination of the evolution of pension accounting helps students acquire a deeper understanding of the specific issues with which the standard setters (and other participants) contended during that evolutionary process. An understanding of these issues enables students to more clearly understand both the provisions of a particular standard and the intricacies of the broader standard setting process. Rather than simply viewing the standard setting process as a system of "due process" involving the issuances of discussion memoranda, exposure drafts, etc., students come to recognize the key issues that drive the development of a standard or a series of related standards. In the specific case of the pension accounting evolution, students become keenly 
aware of contentious measurement issues such as the calculation of pension expense and the accrual of the employer's pension obligation. For example, under the current method of instruction, the "minimum pension liability" is viewed as little more than an arcane measurement that the students must memorize to be able to calculate overall pension expense. Under the proposed method, the discussion of the "minimum pension liability" can be extended to reveal the current deficiencies that may exist in the underlying standard setting process. In effect, the mere necessity of this required measurement of a "minimum" liability implies that the FASB felt that the standard could otherwise fail to report even a minimally acceptable amount of a firm's true pension obligation. The ensuing classroom discussion will likely promote a student understanding of the political nature of the standard setting process that is not likely to occur with the current approach. Thus, the benefit of this approach is twofold in that it promotes a greater understanding of both the standard being addressed and the underlying standard setting process that created it. This enhanced clarity of both the standard setting process and the issues that are pertinent to a given accounting standard provide students with an in-depth understanding of issues - a depth of understanding that normally cannot be attained via conventional teaching pedagogies.

Addressing the Problems of 1) The Typically Abstract Presentation of the Standard Setting Process and 2) The Resulting Potential for Negative Impact on Participation in the Process

With the many extensive accounting regulations that financial accounting textbooks are required to cover, textbook authors understandably find little room for detailed discussion of the evolution of a specific financial reporting issue. For example, the pension accounting evolution (see Figure 7) formally began in 1948 with the issuance of Accounting Research Bulletin No. 36 by the then existing "Committee on Accounting Procedure (CAP)" and continues to this day with the recently revised Statement of Financial Accounting Standards No. 132R (2004). It is therefore quite logical that the standard pension accounting chapter of intermediate accounting textbooks does not provide a discussion of this lengthy evolution. Still, one should not discount the potential benefits of exposing students to the evolution of any particular accounting issue.

Study of the pension accounting evolution provides students with insight into the key - and often times repeating - issues that drive the standard setting debate. In the particular instance of pension accounting, students become aware of the contentious points that have fueled the accounting debate for some six decades. For example, Accounting Research Bulletin No. 36 initiated the notion that the much practiced "pay-as-you-go" approach of that era failed to accrue pension expense in the proper periods and likewise failed to recognize firms' obligations to their workforces for past services. These very issues of pension expense and pension liability_were addressed in subsequent standards such as Accounting Research Bulletin No. 47 (1956), Accounting Principles Board (APB) Opinion No. 8 (1966), SFAS No. 87 (1985) - as well as other pronouncements of the FASB in which matters of pension disclosure were addressed.

By carefully examining the accounting evolution that spawned the various pension standards, students recognize the several recurring themes and thus become more aware of the contentious nature of these issues, the importance of these issues to various (and often times "competing") financial reporting constituents, and the very process by which the standard setters operate. That is, the standard setting process begins to lose its murkiness in the eyes of students and instead becomes something with which they are familiar. And since it is human nature to be comfortable with that with which we are familiar, students become more comfortable with playing a meaningful role in the standard setting process. They would be more inclined to become involved in the standard setting process and to do so in a less self-interested manner.

\section{Addressing the Problems of "Student Boredom" and the Resulting Lack of Retention}

Accounting instructors should have little difficulty understanding why it is that students fail to express enthusiasm over the chapters dealing with the FASB's Conceptual Framework. The series of flowcharts, diagrams, tables, and seemingly endless lists of terms and definitions found within these chapters can hardly be expected to evoke excitement among the students. Here again, however, the proposed teaching pedagogy offers a remedy. Rather than merely being presented with chapter material that they perceive as dull, students are presented with intriguing examples 
of their profession's failure to meet society's needs and the often times contentious ways in which the profession is said to have addressed those needs.

With respect to the pension accounting evolution, students face the interesting challenge of considering whether the specific provisions of SFAS No. 87 and the related "disclosure" standards truly meet the needs of society. Rather than memorizing these various provisions, students could engage in healthy debate as to the adequacy of the standards' provisions, and whether - with regard to certain provisions - the FASB might have conceded to corporate lobbying pressures. By studying the actual evolution of the pension accounting evolution and questioning the extent to which the evolution gradually succeeded in meeting the needs of society, students would be far less likely to find themselves bored by their studies. Of course, a more "interesting" learning process is likely to be a more fruitful learning process. In turn, students' heightened levels of interest would likely lead to a greater sensitivity to the needs of society and, at the same time, foster greater confidence in their ability to offer meaningful contributions to the standard setting process.

\section{CONCLUSION}

The series of high-profile corporate accounting scandals of recent years led to a public outcry for a more transparent and responsible financial reporting process. Society sent out the unequivocal message that the existing process was not only highly flawed, but one that was equally disregarding of meeting the needs of society. One might argue that the most logical place for instilling in business professionals the importance of a high regard for society's needs is the classroom.

This paper discussed the conventional manner in which accounting students are exposed to their profession's societal obligations and cited the deficiencies of this approach. An alternative teaching pedagogy was proposed - one that offers the potential for greater student interest in the subject of their profession's obligations as well as the potential for a more positive and fruitful academic experience. While the pedagogy was illustrated in reference to the topic of pension accounting, it can be applied with respect to any accounting topic, thus making for a more interesting and potentially more fruitful learning process, and one that sensitizes students to their profession's societal obligations. Our hope, and our belief, is that the proposed pedagogy would engender in students not just a greater awareness of their societal obligations, but also a greater desire to help satisfy those obligations.

\section{REFERENCES}

1. Committee on Accounting Procedure, "Pension Plans - Accounting for Annuity Costs Based on Past Services," Accounting Research Bulletin No. 36 (American Institute of Accountants, 1948)

2. Committee on Accounting Procedure, Accounting for Costs of Pension Plans, Accounting Research Bulletin No. 47 (American Institute of Accountants, 1956)

3. Accounting Principles Board, Accounting for the Cost of Pension Plans, APB Opinion No. 8 (American Institute of Certified Public Accountants, 1966).

4. Dyckman, Thomas R., Roland E. Dukes, and Charles J. Davis. Intermediate Accounting $4^{\text {th }}$ edition. (Irwin/McGraw-Hill, 1998).

5. Financial Accounting Standards Board, Objectives of Financial Reporting by Business Enterprises, Statement of Financial Accounting Concepts No.1 (FASB, 1978).Financial Accounting Standards Board, Qualitative Characteristics of Accounting Information, Statement of Financial Accounting Concepts No.2 (FASB, 1980).Financial Accounting Standards Board, Elements of Financial Statements of Business Enterprises, Statement of Financial Accounting Concepts No.3 (FASB, 1980).Financial Accounting Standards Board, Disclosure of Pension Information, Statement of Financial Accounting Standard No.36 (FASB, 1980).

6. Financial Accounting Standards Board, Recognition and Measurement in Financial Statements of Business Enterprises, Statement of Financial Accounting Concepts No.5 (FASB, 1984).Financial Accounting Standards Board, Employers' Accounting for Pensions, Statement of Financial Accounting Standard No.87 (FASB, 1985).

8. Financial Accounting Standards Board, Employers' Accounting for Postretirement Benefits other than Pensions, Statement of Financial Accounting Standard No.106 (FASB, 1990). 
9. Financial Accounting Standards Board, Employers' Accounting for Postemployment Benefits—an amendment of FASB Statements No. 5 and 43, Statement of Financial Accounting Standard No.112 (FASB, 1992).

10. Financial Accounting Standards Board, Employers' Disclosures about Pensions and Other Postretirement Benefits - an amendment of FASB Statements No. 87, 88, and 106, Statement of Financial Accounting Standard No.132 (FASB, 1998).

11. Kieso, Donald E., Jerry Y. Weygandt and Terry D. Warfield. Intermediate Accounting $11^{\text {th }}$ edition, Volume I. (John Wiley \& Sons, Inc., 2004).

12. Nikolai, Loren A. and John D. Bazley. Intermediate Accounting $7^{\text {th }}$ edition. (South-Western, 1997).

13. Spiceland, J. David, James F. Sepe and Lawrence A. Tomassini. Intermediate Accounting $3^{\text {rd }}$ edition. (McGraw-Hill, 2004).

\section{FIGURE 1: Typical Textbook Introduction of the Conceptual Framework Project}

\section{FASB's Conceptual Framework}

In order to guide the development of sound and consistent accounting standards, the Financial Accounting Standards Board has issued the following six Statements of Financial Accounting Concepts (SFAC):

SFAC No. 1. "Objectives of Financial Reporting by Business Enterprises" presents the goals and purposes of accounting.

SFAC No. 2. "Qualitative Characteristics of Accounting Information" examines the characteristics that make accounting information useful.

SFAC No. 3. "Elements of Financial Statements of Business Enterprises" defines the broad classifications of items found in financial statements.

SFAC No. 5. "Recognition and Measurement in Financial Statements of Business Enterprises" gives guidance on what information should be formally incorporated into financial statements and when.

SFAC No. 6. "Elements of Financial Statements" replaces SFAC No. 3 and expands its scope to include not-forprofit organizations.

SFAC No. 7. "Using Cash Flow Information and Present Value in Accounting Measurements," provides a framework for using expected future cash flows and present value as a basis for measurement. 


\section{FIGURE 2: Definitions for Underlying Assumptions, Principles, and Constraints}

\section{$\underline{\text { Basic Assumptions }}$}

Economic Entity Assumption. The economic activities of an entity can be accumulated and reported in a manner that assumes the entity is separate and distinct from its owners or other business units.

Going Concern Assumption. In the absence of contrary information, a business entity is assumed to have a long life. The current relevance of the historical cost principle is dependent on the going-concern assumption.

Monetary Unit Assumption. Money is the common denominator of economic activity and provides an appropriate basis for accounting measurement and analysis. The monetary unit is assumed to remain relatively stable over the years in terms of purchasing power. In essence, this assumption disregards any inflation or deflation in the economy in which the entity operates.

Periodicity Assumption. The life of an economic entity can be divided into artificial time periods for the purpose of providing periodic reports on the economic activities of the entity.

\section{Basic Principles}

Historical Cost Principle. Acquisition cost is considered a reliable basis upon which to account for assets and liabilities of a business enterprise. Cost has been found to be a more stable and consistent benchmark than other suggested valuation methods.

Revenue Recognition Principle. Revenue is recognized (1) when realized or realizable and (2) when earned. Recognition at the time of sale provides a uniform and reasonable test. Certain variations in the revenue recognition principle include: the certain long-term construction contracts, end-of-production recognition, and recognition upon receipt of cash.

Matching Principle. Accountants attempt to match expenses incurred while earning revenues with the related revenues. Use of accrual accounting procedures assists the accountant in allocating revenues and expenses properly among the fiscal periods that compose the life of a business enterprise.

Full Disclosure Principle. In the preparation of financial statements, the accountant should include sufficient information to permit the knowledgeable reader to make an informed judgment about the financial condition of the enterprise in question.

\section{Constraints}

Cost-Benefit Relationship. This constraint relates to the notion that the benefits to be derived from providing certain accounting information should exceed the costs of providing that information. The difficulty in cost-benefit analysis is that the costs and especially the benefits are not always evident or measurable.

Materiality. In the application of basic accounting theory, an amount may be considered less important because of its size in comparison with revenues and expenses, assets and liabilities, or net income. Deciding when an amount is material in relation to other amounts is a matter of judgment and professional expertise.

Industry Practices. Basic accounting theory may not apply with equal relevance to every industry that accounting must serve. The fair presentation of financial position and results of operations for a particular industry may require a departure from basic accounting theory because of the peculiar nature of an event or practice common only to that industry.

Conservatism. When in doubt, an accountant should choose a solution that will be least likely to overstate assets and income. The conservatism constraint should be applied only when doubt exists. An intentional understatement of assets or income is not acceptable accounting. 


\section{FIGURE 3: Definitions of the Financial Statement Elements}

\section{ELEMENTS OF FINANCIAL STATEMENTS}

Assets. Assets are probable future economic benefits obtained or controlled by a particular entity as a result of past transactions or events.

Liabilities. Liabilities are probable future sacrifices of economic benefits arising from present obligations of a particular entity to transfer assets or provide services to other entities in the future as a result of past transactions or events.

Equity. Equity or net assets is the residual interest in the assets of an entity that remains after deducting its liabilities. In a business enterprise, the equity is the ownership interest. In a not-for-profit organization, which has no ownership interest in the same sense as a business enterprise, net assets is divided into three classes based on the presence or absence of donor-imposed restrictions - permanently restricted, temporarily restricted, and unrestricted net assets.

Investments by owners. Investments by owners are increases in equity of a particular business enterprise resulting from transfers to it from other entities of something valuable to obtain or increase ownership interests in it. Assets are most commonly received as investments by owners, but that which is received may also include services or satisfaction or conversion of liabilities of the enterprise.

Distributions to owners. Distributions to owners are decreases in equity of a particular business enterprise resulting from transferring assets, rendering services, or incurring liabilities by the enterprise to owners. Distributions to owners decrease ownership interest in an enterprise.

Comprehensive Income. Comprehensive income is the change in equity of a business enterprise during a period from transactions and other events and circumstances from nonowner sources. It includes all changes in equity during a period except those resulting from investments by owners and distributions to owners.

Revenues. Revenues are inflows or other enhancements of assets of an entity or settlements of its liabilities (or a combination of both) from delivering or producing goods, rendering services, or other activities that constitute the entity's ongoing major or central operations.

Expenses. Expenses are outflows or other using up of assets or incurrences of liabilities (or a combination of both) from delivering or producing goods, rendering services, or carrying out other activities that constitute the entity's ongoing major or central operations.

Gains. Gains are increases in equity from peripheral or incidental transactions of an entity and form all other transactions and other events and circumstances affecting the entity except those that result from revenues or investments by owners.

Losses. Losses are decreases in equity from peripheral or incidental transactions of an entity and from all other transactions and other events and circumstances affecting the entity except those that result from expenses or distributions to owners. 
FIGURE 4: Typical Textbook Treatment of the Accounting Standard Setting Process

\begin{tabular}{|c|c|c|c|}
\hline \multicolumn{4}{|c|}{$\begin{array}{l}\text { UNDERLYING ASSUMPTIONS, } \\
\text { PRINCIPLES \& CONSTRAINTS }\end{array}$} \\
\hline $\begin{array}{l}\text { Assumptions } \\
\text { 1. Economic Entity } \\
\text { 2. Going Concern } \\
\text { 3. Monetary Unit } \\
\text { 4. Periodicity }\end{array}$ & \multicolumn{2}{|c|}{$\begin{array}{l}\text { Principles } \\
\text { 1. } \text { Historical Cost } \\
\text { 2. Revenue } \\
\text { Recognition } \\
\text { 3. Matching } \\
\text { 4. } \\
\text { Full Disclosure }\end{array}$} & $\begin{array}{l}\text { Constraints } \\
\text { 1. } \text { Cost-Benefit } \\
\text { 2. Materiality } \\
\text { 3. Industry Practice } \\
\text { 4. } \text { Conservatism }\end{array}$ \\
\hline \multicolumn{4}{|c|}{$\begin{array}{c}\text { SECONDARY LEVEL:QUALITIES \& ELEMENTS } \\
\text { OF FINANCIAL INFORMATION }\end{array}$} \\
\hline $\begin{array}{l}\text { Qualitative Charac } \\
\text { 1. Primary Qualities } \\
\text { A. Relevance } \\
\text { (1) Predictive Value } \\
\text { (2) Feedback Value } \\
\text { (3) Timeliness } \\
\text { B. Reliability } \\
\text { (1) Verifiability } \\
\text { (2) Representational } \\
\text { Faithfulness } \\
\text { (3) Neutrality } \\
\text { 2. Secondary Qualities } \\
\text { A. Comparability } \\
\text { B. Consistency }\end{array}$ & & $\begin{array}{ll}\text { 1. } & \mathrm{As} \\
\text { 2. } & \mathrm{Li} \\
\text { 3. } & \mathrm{Eq} \\
\text { 4. } & \mathrm{Iny} \\
\text { 5. } & \mathrm{Di} \\
\text { 6. } & \mathrm{Co} \\
\text { 7. } & \mathrm{Re} \\
\text { 8. } & \mathrm{Ex} \\
\text { 9. } & \mathrm{Ga} \\
\text { 10. } & \mathrm{Lo}\end{array}$ & $\begin{array}{l}\text { ements } \\
\text { nts by Owners } \\
\text { in to Owners } \\
\text { ensive Income } \\
\end{array}$ \\
\hline \multicolumn{4}{|c|}{$\begin{array}{l}\text { PRIMARY LEVEL: GOAL \& PURPOSES } \\
\text { OF FINANCIAL ACCOUNTING }\end{array}$} \\
\hline \multicolumn{4}{|c|}{$\begin{array}{l}\text { Objectives } \\
\text { 1. Provide information that is useful in investment and credit decisions. } \\
\text { 2. Provide information that is useful in assessing cash flows. } \\
\text { 3. Provide information about enterprise resources, claims to resources, and } \\
\text { changes in them. }\end{array}$} \\
\hline
\end{tabular}


FIGURE 5: Typical Flowchart Of The Interactions Among Qualities, Criterion, And Users Of Accounting Information

\section{Accounting}

Information Users

Constraints

User-specific Qualities
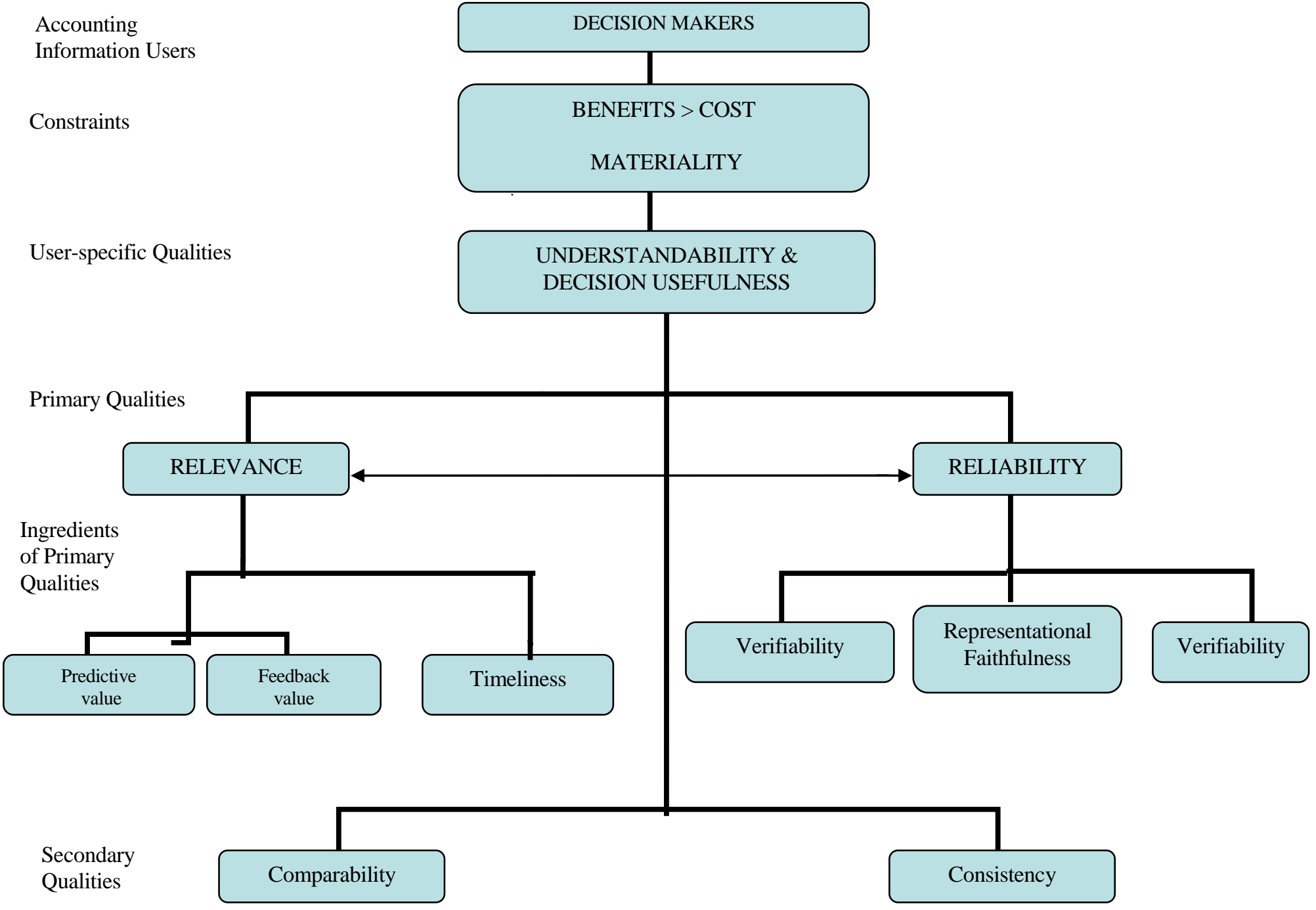


\section{FIGURE 6: Relative Advantages Offered by the Proposed Pedagogy}

\section{Current Problem}

In the classroom, the standard setting process is covered only superficially.

Ultimately, those who are involved in the standard setting process are those who have a vested interest (e.g., analysts, auditors, preparers).

Only the interests of these few groups of financial statement users are represented in the standard setting process.

In the instructional process, there is too much focus on memorization of definitions (neutrality, representational faithfulness, etc.). Manner of instruction with regard to the FASB's Concepts Statements is perceived as tedious and boring; students are thus "turned off" to the issue of the profession's societal obligations.

Rarely if ever are students exposed to an actual creation of an accounting standard; thus the process may seem mysterious and distant.

\section{Solution Offered by Proposed Pedagogy}

Through historical analysis of any given accounting standard, students develop a deeper understanding of the underlying standard setting process.

Through obtainment of a better understanding of the standard setting process, students experience an increased propensity to ultimately participate in that process.

With a deeper understanding of- and greater comfort level with - the standard setting process, students are more likely to participate in the process, and to do so in a way that represents society's needs rather than the needs of select groups.

Rather than memorizing the terms' definitions, students apply the terms to a given topic and thus acquire an understanding of their intended significance.

Students are presented with intriguing examples of the profession's failures with respect to meeting society's neeeds and how it has attempted to address these failures (e.g., accounting for in-substance defeasances, stock compensation, pensions, etc.)

By being exposed to the actual evolution of an accounting standard, students come to appreciate the standard setting process to a far greater degree than they would if they simply study the steps that are followed in the FASB's due process (i.e., discussion memorandum, exposure draft, letters of comment, final pronouncement). 


\section{FIGURE 7: The Evolutionary Nature of the Pension Standard Setting Process}

\begin{tabular}{|c|c|}
\hline $\begin{array}{l}\text { The Accounting Guidance } \\
\text { Governing Pension } \\
\text { Reporting During the Era }\end{array}$ & Observations about the Relevant Guidance at that time. \\
\hline $\begin{array}{l}\text { Prior to any authoritative } \\
\text { reporting guidance }\end{array}$ & $\begin{array}{l}\text { Most firms were taking the simplest route available which was the 'pay as you go' approach. } \\
\text { While this approach was simple, it failed to accrue pension expense to the proper periods and } \\
\text { failed to recognize the obligation that firms could have to their workforce for past services. }\end{array}$ \\
\hline $\begin{array}{l}\text { Committee on Accounting } \\
\text { Procedures' Accounting } \\
\text { Research Bulletin No. } 36 \\
\text { (1948). }\end{array}$ & $\begin{array}{l}\text { ARB No. } 36 \text { recommended that firms record pension benefits that were based on past services } \\
\text { as an expense of current and future accounting periods. Due to nature of the accounting } \\
\text { profession's standard setting process at that time, the conclusions of the CAP were only } \\
\text { recommendations that companies are encouraged to follow. Furthermore, this initial } \\
\text { recommendation was relatively narrow in focus in that it involved only those situations where } \\
\text { pension payments were made to outside agencies such as insurance companies. But } \\
\text { nonetheless it proved to be a starting point in that it initiated the idea that the 'pay as you go' } \\
\text { approach failed to properly accrue pension expense to the periods that were benefited. }\end{array}$ \\
\hline $\begin{array}{l}\text { Committee on Accounting } \\
\text { Procedures' Accounting } \\
\text { Research Bulletin No. } \\
\text { 47(1956). }\end{array}$ & $\begin{array}{l}\text { ARB No. } 47 \text { recommended that firms recognize a liability for unfunded vested benefits. } \\
\text { Again, due to the nature of the standard setting process at that time, the Bulletins were still } \\
\text { only recommendations, and thus could not be mandated. However, it was becoming clearer } \\
\text { that the 'pay as you go' approach misrepresented the financial obligation that companies had } \\
\text { to their workforce for pensions and that the accounting profession was increasingly moving } \\
\text { toward addressing the deficiencies of the "pay as you go" approach. }\end{array}$ \\
\hline $\begin{array}{l}\text { Accounting Principles Board } \\
\text { Opinion No. } 8 \text { (1966). }\end{array}$ & $\begin{array}{l}\text { Opinion No. } 8 \text { initiated a mandated transition from the previous "pay as you go" approach. } \\
\text { Unlike the recommendations of the CAP, the guidance offered by the APB was considered } \\
\text { authoritative and firms were obligated to comply with the provisions of the resulting } \\
\text { Opinions. Associated with the APB's move toward full accrual of pension expense was the } \\
\text { need to address the frequently large amounts of prior service cost that were not being reflected } \\
\text { in the then-existing financial statements. Since most firms were still recognizing their pension } \\
\text { expense on a 'pay-as-you-go' basis, the APB deliberations regarding the move toward } \\
\text { increased accrual of pension expenses and liabilities were predictably contentious. The APB } \\
\text { reacted logically to the contentious nature of the issue by offering an evolutionary standard } \\
\text { that allowed corporations a large degree of latitude in the actuarial methods they selected and } \\
\text { provided windows that the resulting expense and liability measures were allowed to be within. } \\
\text { While firms were typically required to report larger amounts of pension expense and } \\
\text { liabilities, the move was gradual and was part of a expected longer term evolution of pension } \\
\text { standards. This compromise was understandable, predictable, and likely wise. }\end{array}$ \\
\hline $\begin{array}{l}\text { Financial Accounting } \\
\text { Standards Board's Statement } \\
\text { of Financial Accounting } \\
\text { Standards No. } 87 \text { (1985). }\end{array}$ & $\begin{array}{l}\text { SFAS No. } 87 \text { addressed the need for standardizing the measurement techniques used to report } \\
\text { pension expense and liabilities. It also sought to lessen the amount of pension liabilities (i.e., } \\
\text { prior service cost) that were not being reflected within the financial statements. The } \\
\text { continuing move to have pension measures more accurately reflect the true measures were } \\
\text { predictably met with resistance. Accordingly, the requirements of this statement continued to } \\
\text { represent compromises, and the statement was clearly viewed as merely another step in the } \\
\text { continuing evolution of pension guidance. Predictably, the continued compromises of this } \\
\text { interim step required additional footnote disclosure as a means of conveying the information } \\
\text { that was not fully reflected in the resulting financial statements. Interestingly, FASB foresaw } \\
\text { the danger in meeting the need for accurate information via footnote disclosure, and made } \\
\text { statements that clearly indicated that SFAS } 87 \text { was an interim step, warning that appropriate } \\
\text { pension information could never be satisfied via increased disclosure alone. }\end{array}$ \\
\hline $\begin{array}{l}\text { Financial Accounting } \\
\text { Standards Board SFAS } \\
\text { Numbers } 106(1990), 132 \\
(1998), 132 R(2004)\end{array}$ & $\begin{array}{l}\text { The additional guidance offered since SFAS No. } 87 \text { has attempted to further improve pension } \\
\text { reporting entirely through increasingly sophisticated footnote disclosure. This manner of } \\
\text { addressing the deficiencies of pension accounting is relatively palatable to businesses, but } \\
\text { dramatically increases the complexity of pension information. This complexity likely renders } \\
\text { the information useless to all but those who do deal with these reports on a frequent basis. }\end{array}$ \\
\hline
\end{tabular}


NOTES 